\title{
Effect of drought stress on epicuticular wax load in peanut genotypes
}

\author{
Jayant K Solanki, S. K. Sarangi \\ Department of Microbiology and Biotechnology, Bangalore University, JB Campus, Bangalore - 560 056, India.
}

\begin{tabular}{|c|c|}
\hline ARTICLE INFO & ABSTRACT \\
\hline $\begin{array}{l}\text { Article history: } \\
\text { Received on: } 30 / 07 / 2015 \\
\text { Revised on: } 10 / 08 / 2015 \\
\text { Accepted on: } 19 / 08 / 2015 \\
\text { Available online: } 24 / 08 / 2015\end{array}$ & $\begin{array}{l}\text { The changes in epicuticular wax load (EWL) and the leaf temperature in two peanut genotypes such as JL- } 24 \\
\text { (drought susceptible) and K-9 (drought tolerant) was studied under drought stress and its recovery. The drought } \\
\text { stress was induced at different soil moisture level (100\%, } 60 \%, 40 \% \text { and } 20 \% \text { FC) for } 7 \text { days and subsequent } \\
\text { recovery for } 7 \text { days. In both JL-24 and K-9 genotypes, the EWL was found to be increase with the increase in the } \\
\text { intensity of drought stress. However, the increase in EWL in K-9 genotype was found to be significantly higher } \\
\text { than JL-24 genotype. Moreover, the leaf temperature was also found to be increased with the increase in the }\end{array}$ \\
\hline $\begin{array}{l}\text { Key words: } \\
\text { Peanut, genotypes, drought, } \\
\text { epicuticular wax load, leaf } \\
\text { temperature. }\end{array}$ & $\begin{array}{l}\text { intensity of drought stress and the degree of increase in leaf temperature was more pronounced in JL-24 } \\
\text { compared to K-9 genotype. Further, after the recovery of drought stress, the EWL and leaf temperature decreased } \\
\text { consistently in both the genotypes. The results are discussed in terms of the differences in EWL and temperature } \\
\text { of leaf in two genotypes studied under drought stress. }\end{array}$ \\
\hline
\end{tabular}

\section{INTRODUCTION}

Peanut (Arachis hypogaea L.), commonly known as groundnut is source of the fourth most important edible oil and the third most important vegetable protein in the world [1]. However, over $97.6 \%$ of world peanut growing area and about $95.5 \%$ of the total production is concentrated in developing countries, predominantly in Asia and Africa, where the crop is grown mostly under rain-fed conditions [2]. Low rainfall and prolonged dry spells during growth and development stages of crop are the main reasons for low yields in these areas. To cope with the adverse effects of drought, plants have evolved strategies that enable them to survive under stress conditions [3]. Under drought stress, prevention of water loss through aerial parts of the plant is considered as one of the most important mechanism to avoid drought. As a consequence of water-deficit condition, the stomata tend to close to minimize the loss through transpiration. It has been known that the epicuticular wax minimizes cuticular transpiration [4]. Under water-deficit condition, the leaf temperature have been recognized as an indicator of overall plant-water status [5] and used to asses yield under drought stress [6,7]. Therefore, the present work aims to study the effect of drought stress on epicuticular wax load and leaf temperature in peanut genotypes.

* Corresponding Author

Email: jayantbiot@bub.ernet.in

\section{MATERIALS AND METHODS}

\subsection{Plant material and stress imposition}

Seeds of peanut genotypes, namely JL-24 (drought susceptible) and K-9 (drought tolerant) were collected from Acharya N. G. Ranga Agricultural University (ANGRAU), Agriculture Reasearch Station (ARS), Kadiri, Andhra Pradesh, India. The seeds were sown in plastic pots and plants were maintained gravimetrically [8]. All the pots were maintained at $100 \%$ FC (field capacity) and the water was supplied by keeping check on the water loss by ET (Evopo-Transpiration) rate twice a day for 30 days. At the end of $30^{\text {th }}$ day, the pots were allowed to reach $60 \%, 40 \%$ and $20 \% \mathrm{FC}$ by controlled irrigation with an average decrease of $15 \%$ FC/day for the next five days. At the end of $35^{\text {th }}$ day, drought stress were imposed by maintaining pots at different soil moisture content $(100 \%$ FC, control; $60 \%$ FC, mild stress; $40 \%$ FC, moderate stress and $20 \%$ FC, severe stress) for 7 days. After 7 days of drought imposition, the leaf temperature was recorded and the leaves were harvested for the estimation of epicuticular wax load. Following induction of stress, all the pots were supplemented with water upto $100 \%$ FC for the recovery phase for 7 days. At the end of recovery phase, leaf temperature was recorded and the leaves were harvested for the estimation of epicuticular wax load. Throughout the experiment, all the pots were maintained at rain-free condition. 


\subsection{Measurement of epicuticular wax load (EWL)}

Leaf discs were excised from fresh leaf samples with cork borer. For extraction of wax, five (05) discs per sample (area of a disc, $1.54 \mathrm{~cm}^{2}$ ) were dipped for $15 \mathrm{sec}$ in the tube containing $15 \mathrm{ml}$ of chloroform and taken out. The tubes were kept in hot water bath maintained at $60^{\circ} \mathrm{C}$ for $8 \mathrm{~h}$ until the evaporation of chloroform and the wax remained at the bottom in the sticky form. The wax content was estimated by the method as described by Ebercorn [9] with slight modification. A $5 \mathrm{ml}$ of wax reagent was added to each tube and kept at $60^{\circ} \mathrm{C}$ in water bath for $30 \mathrm{~min}$. After cooling, $12 \mathrm{ml}$ of deionized water was added to each tube and the solution was filtered through a filter paper. The absorbance was measured at $590 \mathrm{~nm}$ with spectrophotometer (Shimadzu, UV1800). The wax content was calculated using standard carnauba plant wax and the EWL is expressed as wax load per unit area of leaf $\left(\mathrm{mg} / \mathrm{dm}^{2}\right)$.

\subsection{Measurement of leaf temperature}

The leaf temperature was measured using infrared thermometer (Raytec, Mini Temp.) between $12 \mathrm{pm}$ to $1 \mathrm{pm}$. The IR gun was placed about an inch from the adaxial leaf surface and the temperature $\left(\right.$ in $^{\circ} \mathrm{C}$ ) was recorded.

\section{Statistics analysis}

The experiments were performed in triplicate $(n=3)$. The results are presented as Mean with Standard Deviation (SD). Significance between the results among different treatments was analyzed by multivariate ANOVA followed by Duncan's Multiple Range Test (DMRT) using IBM SPSS Statistics V20.0 software and represented as lower case letters placed at superscript of Mean \pm SD values along every row in the table.

\section{RESULTS}

The effect of drought stress on epicuticular wax load (EWL) and leaf temperature in peanut genotypes was studied and the results are presented as table and figure.

\subsection{Changes in the epicuticular wax load}

The EWL in JL-24 genotype under drought stress ranged from a minimum of $0.903 \mathrm{mg} / \mathrm{dm}^{2}$ at $100 \%$ FC to a maximum of $1.327 \mathrm{mg} / \mathrm{dm}^{2}$ at $20 \% \mathrm{FC}$, whereas, in K-9 genotype, it ranged from a minimum of 1.140 at $100 \% \mathrm{FC}$ to a maximum of 2.147 $\mathrm{mg} / \mathrm{dm}^{2}$ at $20 \% \mathrm{FC}$. Under recovery of drought stress, the EWL was found to $0.873 \mathrm{mg} / \mathrm{dm}^{2}$ and $1.160 \mathrm{mg} / \mathrm{dm}^{2}$ at $100 \% \mathrm{FC}$ in JL24 and K-9 genotypes respectively, whereas, it reached to 1.157 $\mathrm{mg} / \mathrm{dm}^{2}$ and $1.347 \mathrm{mg} / \mathrm{dm}^{2}$ at $20 \%$ FC in JL-24 and K-9 genotypes (Table 1, Fig. 2).

\subsection{Changes in the leaf temperature}

In JL-24 genotype, the leaf temperature under drought ranged from a minimum of $30.13^{\circ} \mathrm{C}$ at $100 \% \mathrm{FC}$ to a maximum of $39.47^{\circ} \mathrm{C}$ at $20 \% \mathrm{FC}$. Whereas, in $\mathrm{K}-9$ genotype, it ranged from a minimum of $29.70^{\circ} \mathrm{C}$ at $100 \% \mathrm{FC}$ to a maximum of $34.50^{\circ} \mathrm{C}$ at $20 \%$ FC. Under recovery of drought stress, the leaf temperature reached to $32.20^{\circ} \mathrm{C}$ and $31.00^{\circ} \mathrm{C}$ in $\mathrm{JL}-24$ and $\mathrm{K}-9$ genotypes at $20 \%$ FC (Table, Fig. 2).

Table 1: Changes in the epicuticular wax load (EWL) and leaf temperature under drought stress and its recovery.

\begin{tabular}{|c|c|c|c|c|c|c|}
\hline S1. No. & Genotypes & $\begin{array}{c}\text { Treatment } \\
\text { FC } \\
\text { (in \%) }\end{array}$ & $\begin{array}{c}\text { EWL } \\
\text { (Under } \\
\text { drought) } \\
\left(\mathrm{mg} / \mathrm{dm}^{2}\right) \\
\text { Mean } \\
\text { SD }\end{array}$ & $\begin{array}{c}\mathbf{T}_{\text {leaf }} \\
\text { (Under } \\
\text { drought) } \\
\left({ }^{\circ} \mathrm{C}\right) \\
\text { Mean } \\
\text { SD }\end{array}$ & $\begin{array}{c}\text { EWL } \\
\text { (Under } \\
\text { recovery) } \\
\left(\mathrm{mg} / \mathrm{dm}^{2}\right) \\
\text { Mean } \\
\text { SD }\end{array}$ & $\begin{array}{c}\mathbf{T}_{\text {leaf }} \\
\text { (Under } \\
\text { recovery) } \\
\left({ }^{\circ} \mathrm{C}\right) \\
\text { Mean } \\
\text { SD }\end{array}$ \\
\hline 1 & & 100 & $\begin{array}{c}0.903 \\
\pm 0.090^{\mathrm{a}}\end{array}$ & $\begin{array}{c}30.13 \\
\pm 0.74^{\mathrm{ab}}\end{array}$ & $\begin{array}{c}0.873 \\
\pm 0.112^{\mathrm{a}}\end{array}$ & $\begin{array}{c}30.47 \\
\pm 0.45^{\mathrm{bc}}\end{array}$ \\
\hline 2 & & 60 & $\begin{array}{c}1.020 \\
\pm 0.056^{\mathrm{ab}}\end{array}$ & $\begin{array}{c}33.13 \\
\pm 0.65^{\mathrm{c}}\end{array}$ & $\begin{array}{c}0.957 \\
\pm 0.050^{\mathrm{a}}\end{array}$ & $\begin{array}{c}30.57 \\
\pm 0.21^{\mathrm{bc}}\end{array}$ \\
\hline 3 & JL-24 & 40 & $\begin{array}{c}1.250 \\
\pm 0.060^{\mathrm{cd}}\end{array}$ & $\begin{array}{c}37.57 \\
\pm 0.59^{\mathrm{e}}\end{array}$ & $\begin{array}{c}1.083 \\
\pm 0.060^{b}\end{array}$ & $\begin{array}{c}31.47 \\
\pm 0.35^{\mathrm{d}}\end{array}$ \\
\hline 4 & & 20 & $\begin{array}{c}1.327 \\
\pm 0.125^{\mathrm{d}}\end{array}$ & $\begin{array}{l}39.47 \\
\pm 0.51^{\mathrm{f}}\end{array}$ & $\begin{array}{c}1.157 \\
\pm 0.045^{\mathrm{bc}}\end{array}$ & $\begin{array}{c}32.20 \\
\pm 0.36^{\mathrm{e}}\end{array}$ \\
\hline 5 & & 100 & $\begin{aligned} & 1.140 \\
\pm & 0.050^{\mathrm{bc}}\end{aligned}$ & $\begin{array}{c}29.70 \\
\pm 0.26^{\mathrm{a}}\end{array}$ & $\begin{aligned} & 1.160 \\
\pm & 0.096^{\mathrm{bc}}\end{aligned}$ & $\begin{array}{c}29.67 \\
\pm 0.45^{\mathrm{a}}\end{array}$ \\
\hline 6 & & 60 & $\begin{array}{c}1.512 \\
\pm 0.107^{\mathrm{e}}\end{array}$ & $\begin{array}{l}31.03 \\
\pm 0.96^{\mathrm{b}}\end{array}$ & $\begin{array}{c}1.247 \\
\pm 0.055^{\mathrm{cd}}\end{array}$ & $\begin{array}{c}30.03 \\
\pm 0.25^{\mathrm{ab}}\end{array}$ \\
\hline 7 & K-9 & 40 & $\begin{array}{c}1.830 \\
\pm 0.092^{\mathrm{f}}\end{array}$ & $\begin{array}{c}32.60 \\
\pm 0.26^{\mathrm{c}}\end{array}$ & $\begin{array}{c}1.323 \\
\pm 0.061^{\mathrm{d}}\end{array}$ & $\begin{array}{c}30.43 \\
\pm 0.32^{\mathrm{bc}}\end{array}$ \\
\hline 8 & & 20 & $\begin{array}{c}2.147 \\
\pm 0.112^{\mathrm{f}}\end{array}$ & $\begin{array}{c}34.50 \\
\pm 0.46^{\mathrm{d}}\end{array}$ & $\begin{array}{c}1.347 \\
\pm 0.057^{\mathrm{d}}\end{array}$ & $\begin{array}{c}31.00 \\
\pm 0.50^{\mathrm{cd}}\end{array}$ \\
\hline
\end{tabular}

Values not sharing same alphabets are significantly different at $\mathrm{p} \geq 0.05$. FC - Field Capacity (in \%), EWL - Epicuticular Wax Load, $\mathbf{T}_{\text {leaf }}$ - Leaf temperature.

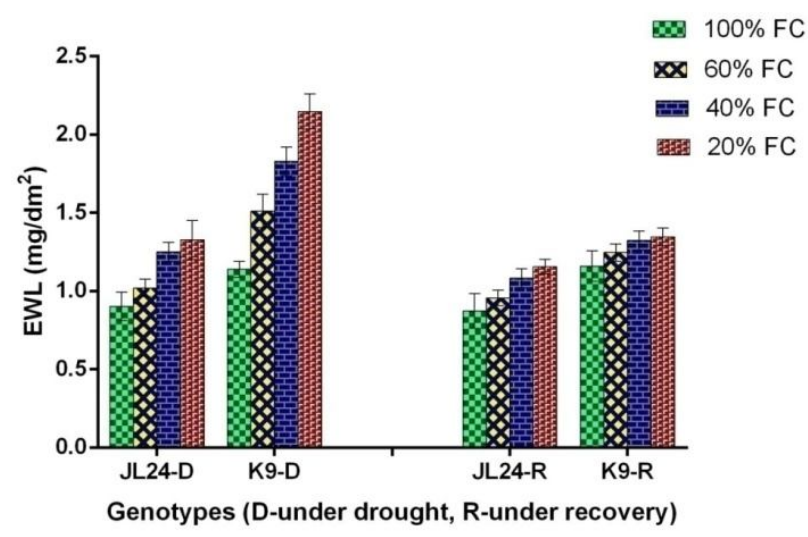

Fig. 1: Changes in the epicuticular wax load (EWL) in the leaf of peanut genotypes under drought stress and its recovery.

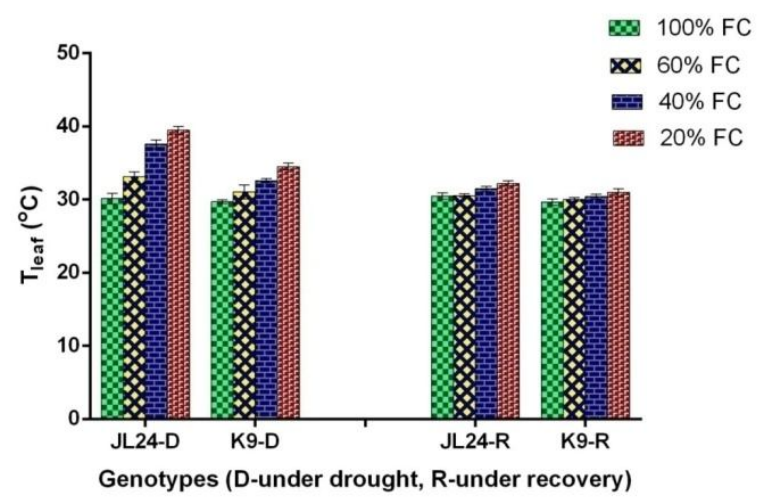

Fig. 2: Changes in the leaf temperature $\left({ }^{\circ} \mathrm{C}\right)$ of peanut genotypes under drought stress and its recovery. 


\section{DISCUSSION}

The results of the present study showed that both JL-24 (drought susceptible) and K-9 (drought tolerant) genotypes differed in EWL on their leaf surface. In control set (100\% FC), the EWL in K-9 genotype was found to be slightly higher than JL24 genotype. Under drought stress, the EWL was found to increase consistently with the intensity of drought stress in both the genotypes. Moreover, the increase in EWL was found to be more significant in K-9 compared to JL-24 genotype. At $20 \%$ FC, the WUE in JL-24 genotype was found to increase by $46.84 \%$ whereas, in K-9 genotype, it increased by $88.33 \%$. Under recovery of drought stress, both the genotypes showed considerable decrease in the EWL. After recovery, the EWL in K-9 genotype at $20 \%$ FC was found to be $16.42 \%$ more than JL-24 genotype. The leaf temperature did not show much change in control sets. Whereas, with the increase in the intensity of drought stress, the leaf temperature was found to increase in both the genotypes. However, the extent of increase in leaf temperature in JL-24 (drought susceptible) was found to be more significant than K-9 (drought tolerant) genotype. Under recovery of drought stress, the leaf temperature decreased in all the stress conditions in both the genotypes. The present findings showed that the tolerant peanut genotype (K-9) showed adaptive response to drought stress by increasing their EWL in the leaf which may assist in lowering the leaf temperature compared to susceptible genotype (JL-24). Although the role of EWL pertaining to drought stress is not clear, it may be predicted that involvement of EWL in drought tolerance is either due to reduction in cuticular transpiration or maintaining lesser leaf surface temperature under water-deficit condition by providing reflective surface for sunlight [10]. Under drought stress, the EWL was found to be increase in several crops such as wheat and pea [11,12]. Moreover, epicuticular waxes are known to improve the efficiency of water use through suppressing transpiration under dehydration in sorghum and peanut $[13,14]$. Studies have also suggested that in peanut genetic variability for leaf-canopy temperature exists $[15,16]$ and it was negatively related with the yield [17].

\section{CONCLUSION}

The present study showed that K-9 (drought tolerant) genotype responds better than JL-24 genotype in their physiological characteristics such as enhancing their EWL in the leaf and lowering leaf temperature under drought stress, which may signifies its relative importance in drought-conditions conditions. Although a thorough investigation is required to assess the contribution of EWL in providing drought tolerance in peanut plant under field conditions.

\section{ACKNOWLEDGEMENTS}

We sincerely thank CSIR, New Delhi, India for the financial assistance to Mr. Jayant K Solanki (CSIR Award No. 09/039(0091)/2009-EMR-1) and the Department of Microbiology and Biotechnology, Bangalore University for providing facilities.
Thanks are due to Dr. K. S. S. Naik, Principal Scientist, ARS, Kadiri, AP, India for providing peanut genotypes.

\section{REFERENCES}

1. CGIAR, Consultive group on International Agricultural Research; 2005. http://www.cgiar.org/impact/researchgroundnut.html

2. ICRISAT, International Crops Research Institute for the Semi- Arid Tropics; 2011. http://www.icrisat.org/crop-groundnut.htm.

3. Timperio AM, Egidi MG and Zolla L. Proteomics applied on plant abiotic stresses: Role of heat shock proteins. J. Proteomics. 2008; 71: 391-411.

4. Premchandra GS, Saneoka H, Fugita K and Ogata S. Leaf water relations, osmotic adjustment, cell membrane stability, epicuticular wax load and growth as affected by increasing water deficit in sorghum. J. Exp. Bot. 1992; 43: 1569-1576.

5. Jackson RD, Idso SB, Reginato RJ, and Pinter PJ, Jr. Canopy temperature as a crop water stress index. Water Resour. Res. 1981; 17: 1133-1138.

6. Blum, A. Plant breeding for stress environments, CRC Press Inc. Boca Raton, FL; 1988.

7. Fischer RA, Rees D, Sayre KD, Lu M, Condon AG and Larque SA. Wheat yield progress associated with higher stomatal conductance and photosynthetic rate and cooler canopies. Crop Sci. 1998; 38: $1467-1475$.

8. Govind G, Harshavardhan VT, Patricia JK, Dhanalakshmi R, Senthil Kumar M Sreenivasulu N, Udayakumar M. Identification and functional validation of a unique set of drought induced genes preferentially expressed in response to gradual water stress in peanut. Mol. Genet. Genomics. 2009; 281: 591-605.

9. Ebercorn A, Blum A and Jordan WR. A rapid colorimetric method for epicuticular wax content of sorghum leaves. Crop Sci. 1977; 17: 179-180.

10. Mohammadian Mansour A, Jennifer R Watling and Robert S Hill. The impact of epicuticular wax on gas-exchange and photoinhibition in Leucadendron lanigerum (Proteaceae). Acta oecologica. 2011; 31.1: 93-101.

11. Merah O, Deleens E, Souyris I, Monneveux P. Effect of glaucousness on carbon isotope discrimination and grain yield in durum wheat. J. Agron. Crop Sci. 2001; 185: 259-265.

12. Sanchez FJ, Manzanares M, De Andre's EF, Tenorio JL, Ayerbe L. Residual transpiration rate, epicuticular wax load and leaf colour of pea plants in drought conditions, Influence on harvest index and canopy temperature. Eur. J. Agron. 2001; 15:57-70.

13. Burow, G. B., Franks, C. D., Xin, Z. (2008), Genetic and physiological analysis of an irradiated bloomless mutant (epicuticular wax mutant) of sorghum, Crop Sci., 48: 41-48.

14. Samdur MY, Manivel P, Jain VK, Chikani BM, Gor HK, Desai S, Misra JB. Genotypic differences and water deficit induced enhancement in epicuticular wax load in peanut. Crop Sci.2003; 43:1294-1299.

15. Nautiyal PC, Rajgopal, K, Zala PV, Pujari DS, Basu M., Dhadhal BA. and Nandre BM. Evaluation of wild Arachis for abiotic stress tolerance: I. Thermal stress and leaf water relations. Euphytica. 2008; 159: 43-57.

16. Chakravarti AK, Moitra A, Mukherjee A, Dey P, Chakraborty PK. Effect of planting methods and mulching on the thermal environment and biological productivity of groundnut. J. Agrometeorol. 2010; 12: 77-80.

17. Mukherjee A, Moitra $\mathrm{R}$ and Chakravarti AK, Variation of micrometeorogical environment within different groundnut cultivars. Environ. Ecol. 2010; 28: 1842-1844.

\section{How to cite this article:}

Solanki JK, Sarangi S.K. Effect of drought stress on epicuticular wax load in peanut genotypes. J App Biol Biotech. 2015; 3 (04): 046-048. 